\title{
PENGGUNAAN EKSTRAK KHAMIR SEBAGAI NUTRISI TAMBAHAN PADA FERMENTASI MOROMI KECAP KEDELAI
}

\section{Use of Yeast Extract as an Additional Nutrition on Soy Sauce Moromi Fermentation}

\author{
Leonie Margaretha Widya Pangestika ${ }^{1,2}$, Hanifah Nuryani Lioe ${ }^{1 *}$, Dede Robiatul Adawiyah ${ }^{1,3}$, \\ S. Suliantari ${ }^{1}$, Guido Melzer ${ }^{4}$, Bernd Weinreich ${ }^{4}$ \\ ${ }^{1}$ Departemen Ilmu dan Teknologi Pangan, Fakultas Teknologi Pertanian, \\ IPB University, Dramaga, Bogor, 16680, Indonesia \\ ${ }^{2}$ Program Studi Biologi, Fakultas Teknobiologi, Universitas Atma Jaya Yogyakarta, \\ Jl. Babarsari no 44, Yogyakarta 55281, Indonesia \\ ${ }^{3}$ Southeast Asian Food \& Agricultural Science and Technology (SEAFAST Center), \\ IPB University, Darmaga, Bogor 16002, Indonesia \\ ${ }^{4}$ Scientific Affairs Division, Leiber GmbH, Bramsche 49565, Jerman \\ *Penulis Korespondensi, email: hanifahlioe@apps.ipb.ac.id
}

Disubmit: 31 Agustus 2020 Direvisi: 28 Desember 2020 Diterima: 16 April 2021

\begin{abstract}
ABSTRAK
Karakteristik kecap kedelai sangat ditentukan oleh aktivitas mikroorganisme yang terlibat selama fermentasi khususnya pada fermentasi tahap kedua dengan larutan garam. Kedelai merupakan substrat yang tinggi protein, dimana hasil fermentasinya seperti kecap kedelai memiliki rasa yang gurih karena kandungan asam amino bebas dan peptida. Bahan yang dapat meningkatkan pertumbuhan mikroorganisme selama fermentasi seperti ekstrak khamir belum pernah diteliti penggunaannya dalam pembuatan kecap kedelai. Penelitian ini bertujuan mengevaluasi pengaruh penambahan ekstrak khamir pada tahap fermentasi garam terhadap karakteristik kimia moromi kecap kedelai. Moromi adalah hasil fermentasi tahap kedua dan disebut kecap kedelai setengah jadi yang belum dimasak dengan gula dan rempah-rempah untuk menghasilkan kecap asin atau kecap manis. Karakteristik moromi yang diinginkan adalah kadar asam glutamat bebas dan padatan terlarut yang tinggi. Pada penelitian ini koji kering difermentasi dalam larutan garam (1:4= koji:larutan garam) $20 \% \mathrm{~b} / \mathrm{v}$ secara spontan. Ekstrak khamir ditambahkan ke dalam larutan garam dengan konsentrasi 0 (M0) sebagai kontrol, 0,05 (M1), 0,15 (M2), dan 0,50 (M3) \% b/v. Karakteristik kimia dari moromi dievaluasi pada hari ke-0, 7, dan kemudian setiap dua minggu sekali hingga hari fermentasi ke-63. Hasil analisis data dengan One-Way ANOVA menunjukkan bahwa karakteristik kimia moromi yang ditambah ekstrak khamir berbeda nyata dengan karakteristik moromi tanpa penambahan ekstrak khamir. Moromi yang ditambah ekstrak khamir 0,50\% b/v (M3) memiliki total gula, total asam tertitrasi, dan kadar asam glutamat yang signifikan lebih tinggi dibanding moromi lain (M1 dan M2). Ekstrak khamir dapat dimanfaatkan sebagai nutrisi tambahan bagi mikroorganisme yang berperan dalam proses pembuatan kecap kedelai
\end{abstract}

Kata kunci : Aktivitas Mikroorganisme; Fermentasi Garam; Ketersediaan Nutrisi; Kualitas Kecap Kedelai

\section{ABSTRACT}

The characteristics of soy sauce are largely determined by the activity of microorganisms involved during fermentation, especially in the second stage of fermentation with brine. Soybeans contained high protein concentration, hence its fermentation result such as soy sauce has a savory taste. Supporting materials such as yeast extract that can boost microbial growth during soy sauce fermentation haven't been studied in soy sauce production. This study aims to evaluate the effect of yeast extract addition in brine fermentation towards chemical characteristics of soy sauce moromi. Moromi is product from second stage of fermentation, called semi-finished soy sauce, that hasn't been cooked with sugar and spices to produce salty or sweet soy sauce. The desired characteristics of moromi are high levels of free glutamic acid and dissolved solids. In this study, dried koji was fermented in brine (1:4 = koji:brine) $20 \%$ w/v spontaneously. 
Yeast extract was added to the brine with concentration 0 (M0) as a control, 0.05 (M1), 0,15 (M2), and 0.50 (M3) $\% w / v$. The chemical characteristics of moromi were evaluated on day 0,7 , and then every two weeks until the 63rd day offermentation. Results of data analysis by One-Way ANOVA showed that the chemical characteristics of moromi with yeast extract addition were significant different with moromi without yeast extract addition. Moromi which added with $0.50 \%$ w/v of yeast extract exhibited a significant higher of total sugar, total titratable acid, and glutamic acid compared to other moromi (M1 and M2). Yeast extract can be used as an additional nutrition for microorganisms in soy sauce production

Keywords : Brine Fermentation; Microorganisms Activity; Nutrition Availability; Soy Sauce Quality

\section{PENDAHULUAN}

Kecap kedelai secara tradisional dibuat melalui dua tahap fermentasi yaitu fermentasi koji dan fermentasi garam. Fermentasi garam dilakukan dalam waktu yang relatif lebih lama yaitu sekitar 2-8 bulan, sedangkan fermentasi koji hanya memerlukan waktu 3 hari (Feng et al., 2015; Gao et al., 2010; Lioe et al., 2004). Selama proses fermentasi garam terjadi perubahan komponen kimia yang membentuk rasa dan aroma sebagai penentu kualitas pada moromi (Gao et al., 2011, Gao et al., 2010). Perubahan yang terjadi merupakan hasil dari aktivitas mikroorganisme, seperti khamir dan bakteri asam laktat (Singracha et al., 2017; Song et al., 2015).

Mikroorganisme yang dapat tumbuh pada kondisi garam tinggi selama fermentasi adalah mikroorganisme halotoleran seperti Tetragenococcus halophilus dan Zyghosaccharomyces rouxii. Tetragenococcus halophilus, merupakan bakteri asam laktat yang dominan tumbuh pada moromi kecap Indonesia (Röling et al., 1994). Bakteri tersebut dapat tumbuh pada lingkungan kaya nutrisi dan pertumbuhannya sangat bergantung pada ketersediaan karbohidrat dalam bentuk yang dapat difermentasi yaitu glukosa (Narvhus dan Axelsson, 2003).

Ketersediaan nutrisi pada moromi menentukan kualitas produk akhir yaitu kecap kedelai karena selama fermentasi garam terjadi perubahan asam amino dan glukosa menjadi berbagai senyawa pembentuk aroma (alkohol, ester, fenol, aldehida, dan keton) oleh aktivitas mikroorganisme (Zhang et al., 2020). Moromi kecap kedelai Indonesia dibuat hanya dengan menggunakan kacang kedelai sebagai bahan baku tunggal (Röling et al., 1994), sedangkan nutrisi yang tersedia pada kedelai berada dalam bentuk yang belum siap digunakan. Penambahan nutrisi yang bersifat ready-to- use dapat menjadi alternatif untuk meningkatkan pertumbuhan mikroorganisme selama fermentasi sehingga dihasilkan moromi kecap kedelai dengan kualitas yang lebih baik.

Salah satu bahan yang dapat dimanfaatkan adalah ekstrak khamir. Ekstrak khamir dilaporkan mengandung nutrien dalam bentuk sederhana, seperti asam amino dan glukosa, yang dapat digunakan dengan mudah dan efektif oleh mikroorganisme (Benthin dan Villadsen, 1996; Hakobyan et al., 2012). Selain itu, ekstrak khamir juga mengandung vitamin dan mineral yang penting bagi pertumbuhan mikroorganisme (Vieira et al., 2016).

Studi terdahulu telah membuktikan peran ekstrak khamir dalam mendukung pertumbuhan dan aktivitas sel mikroorganisme, khususnya bakteri asam laktat, serta produksi metabolitnya (Hakobyan et al., 2012; Li et al., 2011; Pejin et al., 2017). Ekstrak khamir juga telah diaplikasikan pada pembuatan produk pangan seperti sosis kering fermentasi (Campagnol et al., 2011) dan yoghurt (Smith et al., 2014). Namun hingga saat ini, ekstrak khamir belum pernah diaplikasikan dalam pembuatan kecap kedelai. Oleh karena itu, penelitian bertujuan mengevaluasi karakteristik kimia moromi kecap kedelai Indonesia yang diperkaya dengan ekstrak khamir sebagai nutrisi tambahan selama fermentasi garam.

\section{METODE}

Penelitian ini menggunakan bahan baku berupa kacang kedelai kuning nonGMO, inokulum raprima, garam non-yodium, ekstrak khamir dari Leiber $\mathrm{GmbH}$ (Jerman), dan air demineral. Analisis kimia menggunakan bahan kimia kualitas pro-analysis. Kit untuk analisis asam glutamat diperoleh dari R-Biopharm AG, Jerman (Böehringer Mannheim, 2012). 
Peralatan produksi moromi yang digunakan adalah mesin pengupas kedelai, steam-jacket cooker, tampah, kain saring, dan kontainer transparan untuk fermentasi garam. Peralatan yang digunakan untuk persiapan sampel adalah sentrifuge, sedangkan analisis kimia menggunakan alat gelas, oven, soxhlet, kjeldahl, spektrofotometer UV-VIS, refraktometer Abbe, dan $\mathrm{pH}$ meter.

\section{Pembuatan Moromi}

Pembuatan moromi dilakukan menggunakan metode Röling et al. (1994) dengan modifikasi. Produksi moromi diawali dengan pencucian kacang kedelai kuning. Kacang kedelai yang sudah bersih direbus selama 20 menit dan direndam dalam air rebusan. Setelah perendaman selama 2 malam, kacang kedelai dikupas dengan mesin pengupas dan dicuci kembali untuk memisahkan kulit ari dan mengurangi rasa asam yang timbul. Kedelai kembali direbus selama 5 menit dan didinginkan sehingga siap untuk diinokulasi (3 g inokulum raprima per $\mathrm{kg}$ bahan baku kedelai). Selanjutnya, kedelai diinkubasi selama 72 jam pada suhu ruang. Koji dijemur dibawah sinar matahari selama 3-4 hari. Koji yang sudah kering diayak sehingga terpisah satu sama lain dan siap difermentasi dalam larutan garam 20\% $\mathrm{b} / \mathrm{v}$ dengan perbandingan antara koji dan larutan garam adalah 1:4. Ekstrak khamir ditambahkan dengan 4 level konsentrasi, yaitu 0 (M0), 0,05 (M1), 0,15 (M2), dan 0,50 (M3) $\%$ b/v. Fermentasi dilakukan selama 63 hari di bawah sinar matahari. Setiap hari moromi diaduk sebanyak 3 kali (pukul 09.00, 12.00, dan 15.00 WIB) untuk mempertahankan konsentrasi garam pada moromi. Moromi yang dipanen kemudian dilewatkan pada kain saring sehingga diperoleh cairan moromi. Cairan tersebut kemudian disentrifuge pada suhu $4{ }^{\circ} \mathrm{C}$ dengan kecepatan 4000 rpm selama 1 jam untuk memperoleh moromi yang bebas dari lemak. Moromi disaring kembali dengan kertas saring dan diperoleh filtrat moromi. Filtrat moromi dapat digunakan untuk analisis kimia.

\section{Analisis Kimia Moromi}

Analisis kimia yang dilakukan terhadap moromi antara lain analisis proksimat bahan baku kacang kedelai (AOAC, 2012), $\mathrm{pH}$ dengan $\mathrm{pH}$ meter (AOAC, 2012), intensitas warna cokelat dengan metode spektrofotometri $(\lambda=420 \mathrm{~nm})$ (AOAC, 2012), total padatan terlarut dengan refraktometer Abbe (AOAC, 2012), kadar garam dengan metode Mohr (AOAC, 2012), total gula dengan metode Anthrone (Pomeranz dan Meloan, 1994), total asam tertitrasi dengan metode titrimetri (AOAC, 2012), dan konsentrasi asam glutamat dengan metode kolorimetri (Böehringer Mannheim, 2012). Analisis proksimat bahan baku kacang kedelai meliputi penetapan kadar air dengan metode gravimetri, kadar abu dengan metode pengabuan langsung, kadar protein dengan mikro-kjedahl, kadar lemak dengan metode ekstraksi soxhlet, dan kadar karbohidrat dengan metode by difference (AOAC, 2012).

\section{Rancangan Penelitian}

Penelitian ini menggunakan Rancangan Acak Lengkap Faktorial dengan dua faktor, yaitu konsentrasi ekstrak khamir dan lama fermentasi. Konsentrasi ekstrak khamir terdiri atas 4 taraf yaitu 0 (M0), 0,05 (M1), 0,15 (M2), dan 0,50 (M3) \% b/v. Moromi akan diaevaluasi pada hari fermentasi ke-0, 7, 21, 35, 49, dan 63.

\section{Analisis Data}

Data yang diperoleh dianalisis dengan One Way ANOVA dan dilanjutkan Duncan Multiple Range Test (DMRT) untuk mengetahui beda nyata antar level perlakuan dengan tingkat kepercayaan 95\%. Analisis data dilakukan dengan program SPSS Version 22. Pengaruh perbedaan konsentrasi ekstrak khamir terhadap karakteristik kimia dilakukan dengan menghitung koefisien korelasi untuk masing-masing sampel moromi selama fermentasi.

\section{HASIL DAN PEMBAHASAN}

\section{Komposisi Proksimat Kacang Kedelai}

Bahan baku kacang kedelai yang digunakan pada penelitian ini memiliki kadar air $11,02 \%$, abu $4,57 \%$, lemak $18,37 \%$, protein $32,12 \%$, dan karbohidrat 33,91\%. Berdasarkan hasil analisis tersebut, diketahui bahwa komponen terbesar pada kacang kedelai adalah karbohidrat. Apabila dibandingkan dengan studi terdahulu, komposisi kadar protein $(35,87 \%)$ sama besar dengan kadar karbohidrat $(35,63 \%)$ pada kacang kedelai Grobogan (Palupi et al., 2015). Perbedaan komposisi kacang kedelai dapat dipengaruhi oleh perbedaan varietas. Hal menarik yang 
ditemukan adalah kacang kedelai lokal varietas Grobogan mengandung komposisi protein sebesar 35,87\% (Palupi et al., 2015), dimana jumlah tersebut lebih besar dibanding kacang kedelai yang diteliti. Hal tersebut menunjukkan bahwa kacang kedelai lokal memiliki potensi untuk dimanfaatkan sebagai bahan dalam pembuatan kecap kedelai.

\section{Karakteristik Kimia Moromi pH}

Hasil analisis pH moromi selama fermentasi dapat dilihat pada Gambar 1. Pada hari ke-0, dimana fermentasi belum terjadi, pH M0 $(6,49)$ signifikan lebih tinggi dibanding dengan M1, M2, dan M3 (5,83, 5,76, dan 5,77) $(p<0,05)$. Hal tersebut menunjukkan bahwa penambahan ekstrak khamir berpengaruh terhadap keasaman moromi ketika fermentasi belum terjadi.

Pada periode fermentasi berikutnya, $\mathrm{pH}$ keempat sampel moromi signifikan menurun hingga hari fermentasi ke-21 $(p<0,05)$. Penurunan $\mathrm{pH}$ berperan sebagai indikator terjadinya fermentasi oleh bakteri asam laktat yang mengkonversi glukosa menjadi asam organik (Singracha et al., 2017). Setiap sampel memiliki pola perubahan $\mathrm{pH}$ yang berbeda. Hal tersebut dapat terjadi karena adanya perbedaan jumlah mikroorganisme yang tumbuh pada masing-masing kontainer sampel melalui fermentasi spontan. Jumlah dan aktivitas mikroorganisme selama fermentasi tidak dievaluasi pada penelitian ini. Meskipun demikian, selama fermentasi garam, tren perubahan $\mathrm{pH}$ masing-masing moromi cenderung stagnan.

Hubungan antara level konsentrasi ekstrak khamir terhadap $\mathrm{pH}$ yang ditunjukkan melalui nilai koefisien korelasi dapat dilihat pada Tabel 1. Hasil analisis tersebut menunjukkan bahwa konsentrasi ekstrak khamir memiliki korelasi yang kuat terhadap $\mathrm{pH}$ sampel moromi M0, M1, M2, dan M3 $(R=0,736,0,850,0,760$, dan 0,827) selama fermentasi.

Pada akhir fermentasi, hari ke-63, pH antar sampel moromi tidak berbeda satu sama lain yaitu 5,52 - 5,58 ( $p>0,05)$. Hal tersebut menunjukkan bahwa penambahan ekstrak khamir tidak mempengaruhi $\mathrm{pH}$ akhir moromi. Moromi dengan $\mathrm{pH}$ akhir di atas 5,0 tergolong moromi yang ideal karena $\mathrm{pH}$ yang kurang dari 5,0 memberikan dampak negatif terhadap karakteristik sensori moromi (Hoang et al., 2016). Di sisi lain, um- umnya pada proses fermentasi garam terjadi penurunan $\mathrm{pH}$ hingga di bawah 5,0. Kondisi tersebut dapat menghentikan aktivitas bakteri asam laktat dan mendorong pertumbuhan khamir seperti Zygosccharomyces rouxii untuk menghasilkan alkohol dan berbagai komponen flavor lain (Hoang et al., 2016). Moromi sampel memiliki pH akhir di atas 5,0, sehingga tidak memungkinkan adanya pertumbuhan khamir. Oleh karena itu, diduga senyawa aroma yang terbentuk pada moromi sampel lebih dikontribusi oleh aktivitas bakteri asam laktat dan reaksi Maillard selama fermentasi garam (Gao et al., 2011; Lertsiri et al., 2001).

\section{Intensitas Warna Cokelat}

Warna cokelat pada moromi dihasilkan melalui reaksi Maillard yang terjadi selama fermentasi garam (Gao et al., 2011). Reaksi Maillard merupakan reaksi yang berperan penting dalam fermentasi garam karena tidak hanya berkontribusi dalam pembentukan warna cokelat tetapi juga dalam pembentukan komponen flavor pada moromi (Gao et al., 2011; Lertsiri et al., 2001).

Hasil analisis intensitas warna cokelat selama fermentasi dapat dilihat pada Gambar 2. Sebelum proses fermentasi berlangsung yaitu pada hari fermentasi ke-0, terdapat perbedaan intensitas warna cokelat yang signifikan antar sampel, kecuali antara moromi M0 dan M1. Hal tersebut menunjukkan bahwa ekstrak khamir dapat berkontribusi dalam pembentukan warna cokelat bahkan sebelum fermentasi dimulai. Peningkatan intensitas warna cokelat terjadi secara signfikan hingga hari fermentasi ke-35 untuk M0 dan M2 dan hari fermentasi ke-49 untuk M1 dan M3 ( $<<0,05)$. Pada tahap ini, asam amino dan gula dari koji berdifusi ke larutan garam, bereaksi dan menghasilkan warna cokelat (Lertsiri et al., 2001). Peningkatan intensitas warna cokelat selama fermentasi garam telah dilaporkan pada beberapa studi terdahulu (Gao et al., 2011; Lertsiri et al., 2001).

Pada periode fermentasi berikutnya, intensitas warna cokelat mengalami penurunan hingga akhir fermentasi. Hal tersebut sejalan dengan adanya penurunan total gula akibat penggunaan gula oleh mikroorganisme selama fermentasi garam. Pada akhir fermentasi, moromi M3 memiliki intensitas warna cokelat $(2,408)$ yang signifikan lebih tinggi dibanding sampel moromi lain $(2,320,2,168$, dan 2,290, berurutan untuk M0, M1, dan M2). 
Tabel 1. Persamaan regresi dan nilai R sebagai hubungan antara konsentrasi ekstrak khamir terhadap karakteristik kimia moromi selama fermentasi

\begin{tabular}{|c|c|c|c|c|c|c|c|}
\hline Parameter & Sampel & Persamaan regresi & $\begin{array}{c}\text { Nilai } \\
\text { R }\end{array}$ & Parameter & Sampel & Persamaan regresi & $\begin{array}{c}\text { Nilai } \\
\text { R }\end{array}$ \\
\hline \multirow[t]{4}{*}{$\mathrm{pH}$} & M0 & $y=-0,0107 x+6,0868$ & 0,736 & & M2 & $y=-0,0555 x+18,217$ & 0,950 \\
\hline & M1 & $y=-0,0035 x+5,759$ & 0,850 & & M3 & $y=-0,0489 x+18,192$ & 0,963 \\
\hline & M2 & $y=-0,0039 x+5,6959$ & 0,760 & Total gula & M0 & $y=0,00003 x+0,54712$ & 0,004 \\
\hline & M3 & $y=-0,0032 x+5,7154$ & 0,827 & & M1 & $y=-0,002 x+0,5589$ & 0,350 \\
\hline \multirow{4}{*}{$\begin{array}{l}\text { Intensitas } \\
\text { warna } \\
\text { cokelat }\end{array}$} & M0 & $y=0,0184 x+1,45$ & 0,871 & & M2 & $y=-0,0002 x+0,5843$ & 0,026 \\
\hline & M1 & $y=0,0257 x+1,3596$ & 0,949 & & M3 & $y=-0,0005 x+0,6142$ & 0,082 \\
\hline & M2 & $y=0,0135 x+1,6328$ & 0,886 & $\begin{array}{c}\text { Total asam } \\
\text { tertitrasi }\end{array}$ & M0 & $y=0,0012 x+0,0547$ & 0,825 \\
\hline & M3 & $y=0,011 x+1,8014$ & 0,949 & & M1 & $y=0,0012 x+0,0626$ & 0,800 \\
\hline \multirow{4}{*}{$\begin{array}{l}\text { Total } \\
\text { padatan } \\
\text { terlarut }\end{array}$} & M0 & $y=0,0118 x+23,142$ & 0,373 & & M2 & $y=0,0013 x+0,0577$ & 0,838 \\
\hline & M1 & $y=-0,0013 x+23,054$ & 0,032 & & M3 & $y=0,0015 x+0,059$ & 0,902 \\
\hline & M2 & $y=0,0257 x+22,933$ & 0,457 & $\begin{array}{c}\text { Konsentrasi } \\
\text { asam } \\
\text { glutamat }\end{array}$ & M0 & $y=0,002 x+0,0693$ & 0,921 \\
\hline & M3 & $y=0,0034 x+24,296$ & 0,119 & & M1 & $y=0,002 x+0,0814$ & 0,862 \\
\hline \multirow{2}{*}{$\begin{array}{l}\text { Kadar } \\
\text { garam }\end{array}$} & M0 & $y=-0,0079 x+16,038$ & 0,319 & & M2 & $y=0,0022 x+0,0931$ & 0,850 \\
\hline & M1 & $y=-0,0173 x+15,449$ & 0,484 & & M3 & $y=0,0024 x+0,098$ & 0,887 \\
\hline
\end{tabular}

M0 = tanpa penambahan ekstrak khamir; M1 = penambahan ekstrak khamir 0,05\% b/v;M2= penambahan ekstrak khamir $0,15 \% \mathrm{~b} / \mathrm{v} ; \mathrm{M} 3=$ penambahan ekstrak khamir $0,50 \% \mathrm{~b} / \mathrm{v}$

Tabel 2. Besar peningkatan konsentrasi asam glutamat pada masing-masing sampel setelah 63 hari fermentasi

\begin{tabular}{cc}
\hline Sampel & Besar peningkatan $(\% \mathbf{b b})$ \\
\hline M0 & $0,139 \pm 0,000^{\mathrm{c}}$ \\
M1 & $0,147 \pm 0,000^{\mathrm{bc}}$ \\
M2 & $0,155 \pm 0,002^{\mathrm{b}}$ \\
M3 & $0,173 \pm 0,005^{\mathrm{a}}$ \\
\hline
\end{tabular}

$\overline{\mathrm{M} 0}=$ tanpa penambahan ekstrak khamir; M1 = penambahan ekstrak khamir 0,05\% b/v; M2= penambahan ekstrak khamir $0,15 \% \mathrm{~b} / \mathrm{v} ; \mathrm{M} 3=$ penambahan ekstrak khamir $0,50 \% \mathrm{~b} / \mathrm{v}$

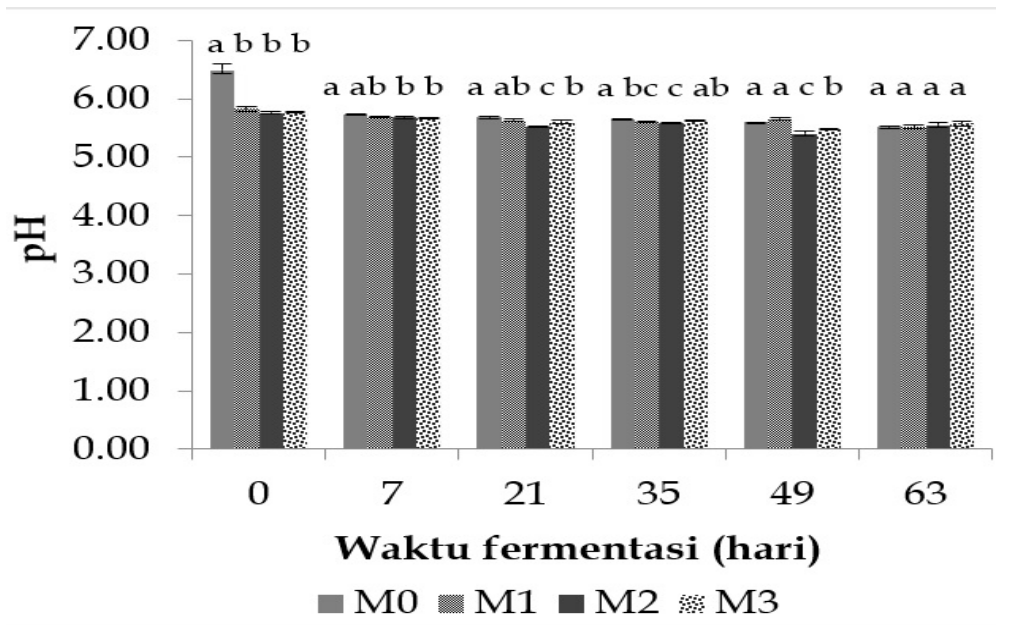

Gambar 1. Perubahan karakteristik $\mathrm{pH}$ moromi selama 63 hari fermentasi garam. $\mathrm{M} 0=$ tanpa penambahan ekstrak khamir; M1= penambahan ekstrak khamir 0,05\% b/v ; M2= penambahan ekstrak khamir 0,15\% b/v; M3= penambahan ekstrak khamir 0,50\% b/v. Notasi menunjukkan perbedaan antar sampel pada masing-masing waktu fermentasi 
Nilai koefisien korelasi yang menunjukkan hubungan antara level konsentrasi ekstrak khamir terhadap intensitas warna cokelat dapat dilihat pada Tabel 1. Hasil analisis tersebut menunjukkan bahwa perbedaan konsentrasi ekstrak khamir yang digunakan memiliki korelasi yang kuat terhadap intensitas warna cokelat pada sampel moromi M0 dan M2 ( $\mathrm{R}=0,871$ dan 0,886$)$, serta korelasi yang sangat kuat pada sampel moromi M1 dan M3 ( $R=0,949$ dan 0,949) selama fermentasi. Penambahan ekstrak khamir mendorong pembentukan warna cokelat pada moromi karena proses fermentasi yang lebih intense terjadi, dan ini menyediakan asam amino bebas dan gula sederhana yang merupakan prekursor reaksi Maillard (Vieira et al., 2016).

\section{Total Padatan Terlarut}

Total padatan terlarut merupakan salah satu parameter penting yang menggambarkan kualitas dari moromi kecap kedelai. Komponen pada moromi yang dapat terukur sebagai total padatan terlarut adalah gula, asam organik, senyawa aromatik (Chen et al., 2012), dan garam.

Hasil analisis total padatan terlarut selama fermentasi dapat dilihat pada Gambar 3. Hasil analisis menunjukkan bahwa total padatan terlarut dari masing-masing sampel pada hari fermentasi ke-0 yaitu 22,03-23,93 ${ }^{\circ}$ Brix. Tingginya total padatan terlarut pada moromi dikontribusi oleh garam yang ditambahkan pada awal fermentasi, serta gula dan asam amino dari ekstrak khamir. Pada hari fermentasi ke-7, terjadi kenaikan total padatan terlarut yang sejalan dengan kenaikan total gula hingga hari fermentasi ke-35. Penurunan total padatan terlarut terjadi pada hari fermentasi ke-49 hingga akhir fermentasi pada sampel M1, M2, dan M3.

\section{Kadar Garam}

Garam adalah komponen penting dalam fermentasi moromi kecap kedelai. Penambahan garam konsentrasi tinggi (20\%) bertujuan memastikan bahwa hanya mikroorganisme halotoleran yang tumbuh pada sampel moromi. Untuk mempertahankan kadar garam pada moromi selama fermentasi, dilakukan penambahan air demineral hingga mencapai volume $1500 \mathrm{ml}$ (volume awal moromi) pada hari fermentasi ke- 7, 21, 35, 49, dan 63.

Ketika koji dicampurkan dalam larutan garam, partikel garam mengalami per- measi ke dalam koji (Zhang et al., 2016). Hal tersebut menyebabkan konsentrasi garam yang terukur dalam cairan moromi pada hari fermentasi ke-0 kurang dari $20 \%$ $(14,454-18,514 \%)$ (Gambar 4). Pada periode fermentasi berikutnya, masing-masing sampel moromi memiliki pola perubahan yang berbeda. Moromi M3 secara konsisten mengalami penurunan konsentrasi garam. Sebaliknya, moromi M0 cenderung mengalami kenaikan konsentrasi garam hingga hari fermentasi ke-35. Beberapa penelitian terdahulu telah melaporkan bahwa perubahan konsentrasi garam dapat bersifat fluktuatif selama fermentasi disebabkan oleh beberapa faktor seperti evaporasi air akibat penjemuran moromi, permeasi garam ke dalam koji dan likuifikasi bahan baku (Song et al., 2015; Zhang et al., 2016).

Nilai koefisien korelasi yang menunjukkan hubungan antara level konsentrasi ekstrak khamir terhadap kadar garam dapat dilihat pada Tabel 1. Hasil analisis tersebut menunjukkan bahwa perbedaan konsentrasi ekstrak khamir yang digunakan memiliki korelasi yang lemah terhadap kadar garam pada sampel moromi M0 $(\mathrm{R}=0,319)$, korelasi yang moderat pada sampel moromi M1 $(R=0,484)$, serta korelasi yang sangat kuat pada sampel moromi M2 dan M3 ( $R=0,950$ dan 0,963). Hal ini karena ekstrak khamir mengandung garam $\mathrm{NaCl}$, sehingga penambahan ekstrak khamir yang lebih tinggi memberikan konsentrasi $\mathrm{NaCl}$ yang lebih besar pada moromi.

\section{Total Gula}

Selama fermentasi garam, terjadi proses perombakan karbohidrat pada kedelai oleh enzim amilase (Gao et al., 2011). Pada umumnya gula yang terukur pada moromi berasal dari bahan baku kacang kedelai antara lain monosakarida glukosa, fruktosa dan galaktosa, disakarida dan trisakarida seperti sukrosa, maltosa, dan rafinosa (Röling et al., 1994). Gula merupakan komponen penting pada moromi karena berperan sebagai sumber karbon bagi mikroorganisme dalam pembentukan senyawa aroma (Hoang et al., 2016).

Hasil analisis total gula selama fermentasi dapat dilihat pada Gambar 5. Pada hari fermentasi ke-0, total gula pada moromi M3 $(0,482 \% \mathrm{bb})$ signifikan lebih tinggi dibanding moromi M0, M1, dan M2 $(0,419,0,408$, dan $0,453 \% \mathrm{bb}$ ). Hal tersebut menunjukkan bahwa ekstrak khamir memiliki kandungan gula (Vieira et al., 2016), sehingga penambahan ek- 
strak khamir dengan konsentrasi yang lebih tinggi menyediakan gula dalam jumlah yang juga lebih tinggi. Kenaikan total gula ditunjukkan oleh seluruh sampel pada periode fermentasi berikutnya $(p<0,05)$ dan mencapai puncak pada hari fermentasi ke-35. Penurunan total gula yang signifikan terjadi pada hari fermentasi ke-49. Hal tersebut dapat disebabkan oleh beberapa faktor seperti denaturasi enzim pada larutan garam, pemanfaatan gula oleh mikroorganisme atau reaksi Maillard (Yanfang et al., 2009). Pola perubahan pada total gula selama fermentasi yang serupa dilaporkan pada beberapa penelitian terdahulu (Singracha et al., 2017; Song et al., 2015). Pada akhir fermentasi yaitu hari ke63, moromi M3 memiliki total gula tertinggi dibanding moromi M0, M1, dan M2 ( $\mathrm{p}<0,05)$, yaitu $0,405 \%$ bb. Penambahan ekstrak khamir menyediakan gula tambahan yang dapat dimanfaatkan oleh mikroorganisme selama fermentasi garam.

Nilai koefisien korelasi yang menunjukkan hubungan antara level konsentrasi ekstrak khamir terhadap total gula dapat dilihat pada Tabel 1. Hasil analisis tersebut menunjukkan bahwa perbedaan konsentrasi ekstrak khamir yang digunakan tidak memiliki korelasi terhadap total gula pada sampel M0, M2, dan M3 ( $R=0,004,0,026$, dan 0,082), dan korelasi yang lemah terhadap total gula pada sampel moromi M1 $(R=0,350)$. Dengan demikian, fermentasi moromi lebih kuat terjadi pada hidrolisis protein dibanding dengan hidrolisis karbohidrat.

\section{Total Asam Tertitrasi}

Hasil analisis perubahan total asam tertitrasi selama fermentasi dapat dilihat pada Gambar 6. Selama fermentasi, terjadi peningkatan total asam yang signifikan pada moromi dari $0,031-0,038 \%$ bb pada hari ke-0 menjadi 0,124-0,153\% bb pada hari ke-63. Hal tersebut menjadi indikator adanya pertumbuhan dan aktivitas bakteri asam laktat mengubah karbohidrat dalam bentuk gula menjadi asam organik (Singracha et al., 2017). Salah satu bakteri asam laktat yang dapat tumbuh di kondisi garam tinggi moromi adalah Tetragenococcus halophilus. Kebutuhan Tetragenococcus halophilus terhadap nutrisi yang siap digunakan dapat didukung melalui penambahan ekstrak khamir, seperti yang dilaporkan pada studi lain terhadap bakteri asam laktat Lactobacillus (Narvhus dan Axelsson, 2003; Pejin et al., 2017). Hal terse- but dibuktikan melalui hasil analisis yang menunjukkan bahwa moromi M3 dengan penambahan ekstrak khamir sebanyak 0,50\% b/v memiliki total asam yang signifikan lebih tinggi dibanding moromi lain pada akhir fermentasi $(\mathrm{p}<0,05)$.

Pengaruh konsentrasi ekstrak khamir terhadap total asam tertitrasi juga dinyatakan dalam nilai koefisien korelasi yang dapat dilihat pada Tabel 1. Hasil analisis tersebut menunjukkan bahwa perbedaan konsentrasi ekstrak khamir yang digunakan memiliki korelasi yang kuat terhadap total asam tertitrasi pada sampel moromi M0, M1, dan M2 $(\mathrm{R}=0,825,0,800$, dan 0,838$)$ dan korelasi yang sangat kuat terhadap total asam tertitrasi pada sampel moromi M3 $(\mathrm{R}=0,902)$. Total asam tertitrasi yang lebih tinggi ini disebabkan pertumbuhan mikroorganisme (khususnya bakteri asam laktat) yang lebih tinggi (Röling et al., 1994).

\section{Konsentrasi Asam Glutamat}

Asam glutamat merupakan asam amino penting pada moromi yang berkontribusi dalam memberi rasa umami pada kecap kedelai (Gao et al., 2011). Selama fermentasi garam, konsentrasi asam glutamat pada sampel moromi, M0, M1, M2, dan M3, mengalami peningkatan yang signifikan (Gambar 7). Hal tersebut menunjukkan bahwa selama fermentasi terjadi hidrolisis protein menjadi asam amino bebas dan ini ditunjukkan dengan peningkatan konsentrasi asam glutamat bebas pada moromi. Mekanisme produksi asam glutamat pada fermentasi kecap kedelai dapat melalui dua jalur yaitu aktivitas glutaminase yang mengubah glutamin menjadi glutamat dan aktivitas enzim proteolitik pada bakteri asam laktat (Ito et al., 2013). Glutaminase dapat dihasilkan oleh beberapa jenis kapang, seperti Rhizopus oligosporus, Aspergillus oryzae, Aspergillus sojae (Han et al., 2003; Ito et al., 2013), sedangkan aktivitas enzim proteolitik berasal dari enzim intraseluler aminopeptidase yang mengkonversi peptida atau oligopeptida dari kedelai menjadi asam glutamat dan asam amino lain (Udomsil et al., 2010). Setiap strain bakteri asam laktat memiliki tingkat aktivitas produksi asam amino yang spesifik. Penelitian terdahulu telah melaporkan bahwa strain tertentu dari Tetragenococcus halophilus yang tumbuh pada kecap memiliki aktivitas produksi asam glutamat yang tinggi (Udomsil et al., 2010). 
Jurnal Teknologi Pertanian Vol. 22 No. 1 [April 2021] 1-12

Penggunaan Ekstrak Khamir Sebagai Nutrisi Tambahan Pada Fermentasi Moromi [Lioe dkk]

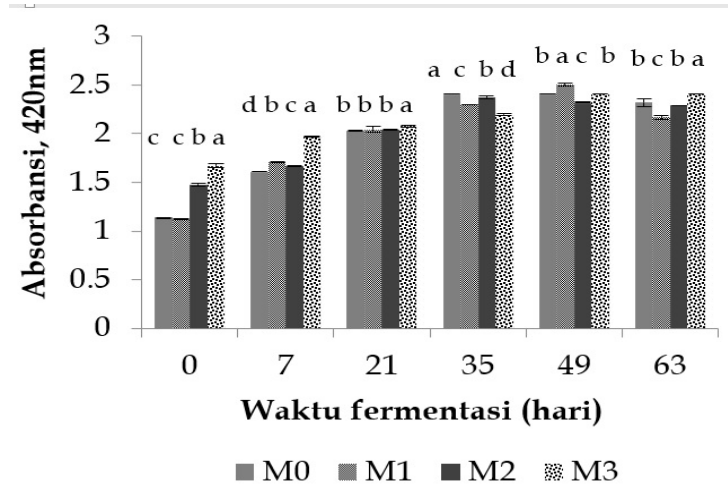

Gambar 2. Perubahan karakteristik intensitas warna cokelat moromi selama 63 hari fermentasi garam. $\mathrm{M} 0=$ tanpa penambahan ekstrak khamir; $\mathrm{M} 1=$ penambahan ekstrak khamir $0,05 \% \mathrm{~b} / \mathrm{v}$; M2= penambahan ekstrak khamir 0,15\% b/v; M3= penambahan ekstrak khamir 0,50\% b/v.

Notasi menunjukkan perbedaan antar sampel pada masing-masing waktu fermentasi

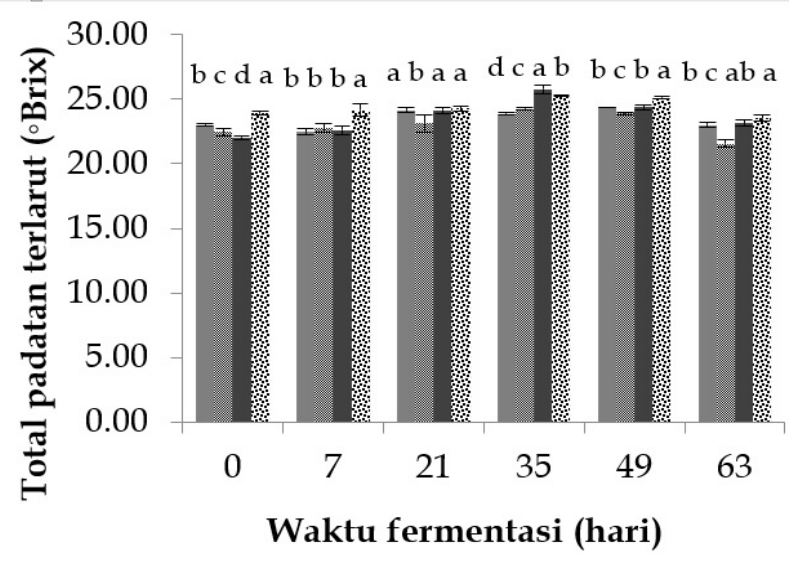

$\square \mathrm{M} 0 \square \mathrm{M} 1 \square \mathrm{M} 2$ 䌇 $\mathrm{M} 3$

Gambar 3. Perubahan karakteristik total padatan terlarut moromi selama 63 hari fermentasi garam. $\mathrm{M} 0=$ tanpa penambahan ekstrak khamir; M1= penambahan ekstrak khamir 0,05\% b/v ; M2= penambahan ekstrak khamir 0,15\% b/v; M3= penambahan ekstrak khamir 0,50\% b/v. Notasi menunjukkan perbedaan antar sampel pada masing-masing waktu fermentasi

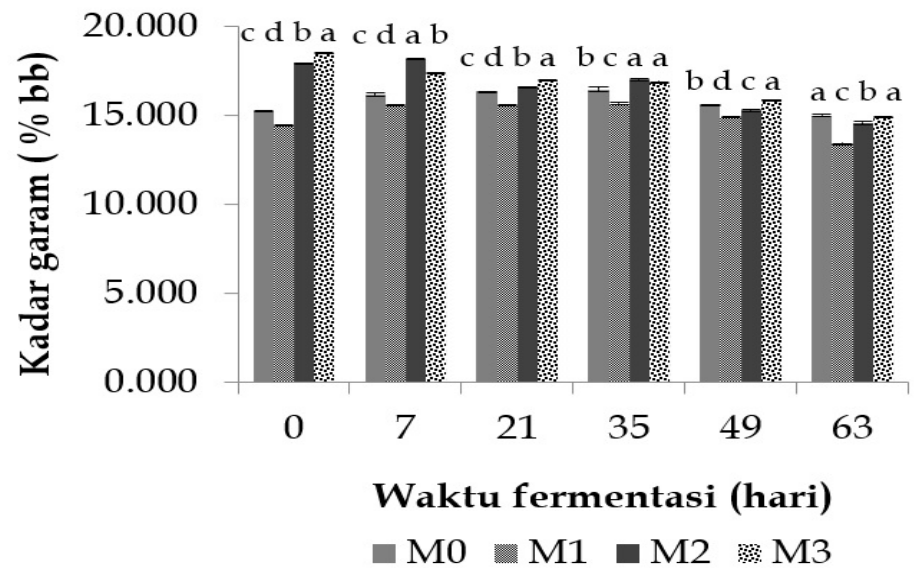

Gambar 4. Perubahan karakteristik kadar garam moromi selama 63 hari fermentasi garam. $\mathrm{M} 0=$ tanpa penambahan ekstrak khamir; $\mathrm{M} 1=$ penambahan ekstrak khamir 0,05\% b/v ; M2= penambahan ekstrak khamir 0,15\% b/v; M3= penambahan ekstrak khamir 0,50\% b/v. Notasi menunjukkan perbedaan antar sampel pada masing-masing waktu fermentasi 


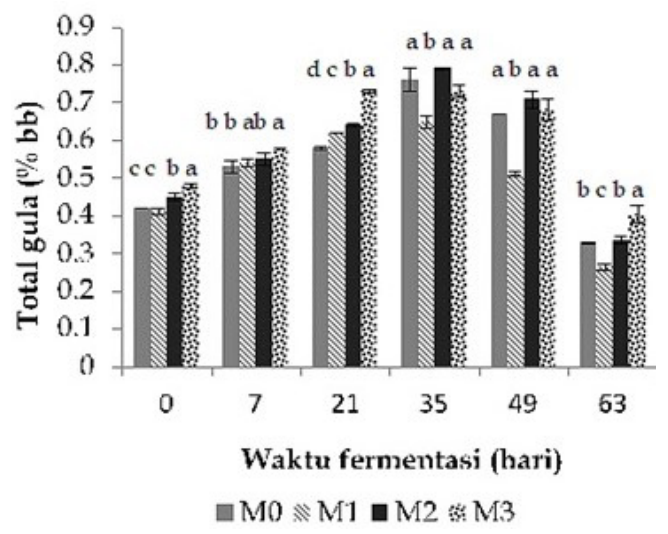

Gambar 5. Perubahan karakteristik total gula moromi selama 63 hari fermentasi garam. $\mathrm{M} 0=$ tanpa penambahan ekstrak khamir; M1= penambahan ekstrak khamir 0,05\% b/v ; M2= penambahan ekstrak khamir 0,15\% b/v; M3= penambahan ekstrak khamir 0,50\% b/v. Notasi menunjukkan perbedaan antar sampel pada masing-masing waktu fermentasi

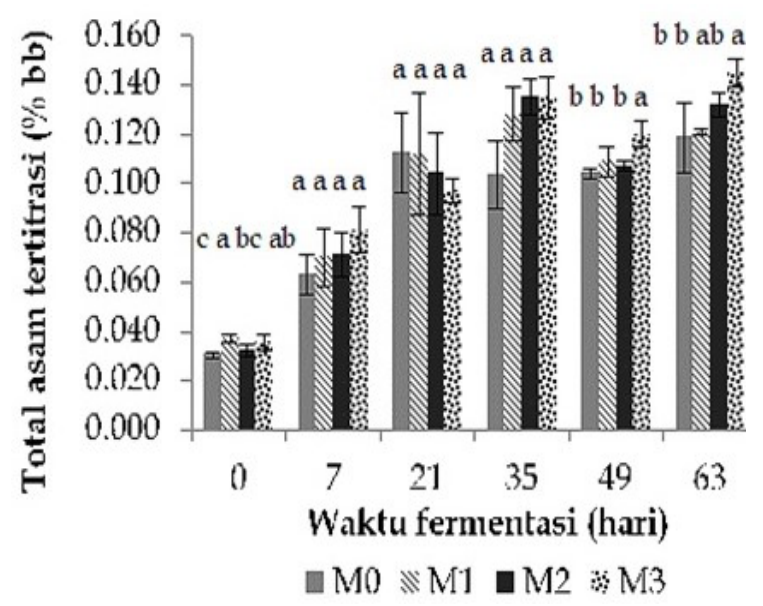

Gambar 6. Perubahan karakteristik toal asam tertitrasi moromi selama 63 hari fermentasi garam. $\mathrm{M} 0=$ tanpa penambahan ekstrak khamir; $\mathrm{M} 1=$ penambahan ekstrak khamir 0,05\% b/v ; M2= penambahan ekstrak khamir 0,15\% b/v; M3= penambahan ekstrak khamir 0,50\% b/v. Notasi menunjukkan perbedaan antar sampel pada masing-masing waktu fermentasi

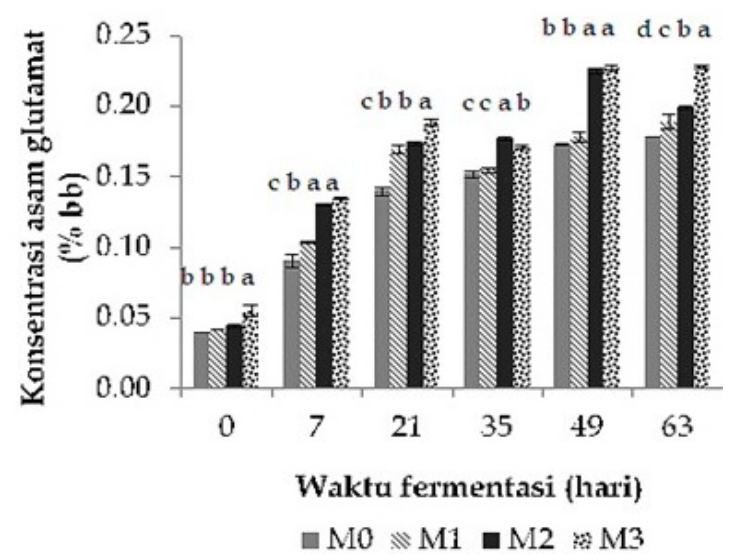

Gambar 7. Perubahan karakteristik konsentrasi asam glutamat selama 63 hari fermentasi garam. $\mathrm{M} 0=$ tanpa penambahan ekstrak khamir; $\mathrm{M} 1=$ penambahan ekstrak khamir 0,05\% b/v ; M2= penambahan ekstrak khamir 0,15\% b/v; M3= penambahan ekstrak khamir 0,50\% b/v. Notasi menunjukkan perbedaan antar sampel pada masing-masing waktu fermentasi 
Peningkatan konsentrasi ekstrak khamir yang diaplikasikan memberikan pengaruh pada besar kenaikan konsentrasi asam glutamat. Konsentrasi asam glutamat pada M3 menunjukkan peningkatan yang signifikan lebih besar dibanding pada M0, M1, dan M2 $(\mathrm{p}<0,05)$, sedangkan M1 tidak berbeda signifikan dengan M0 dan M2 (Tabel 2). Hasil analisis tersebut menunjukkan bahwa ekstrak khamir yang ditambahkan pada moromi menyediakan nutrisi tambahan bagi mikroorganisme, sehingga dengan konsentrasi ekstrak khamir yang lebih tinggi, terjadi peningkatan produksi asam glutamat yang lebih besar.

Nilai koefisien korelasi yang menunjukkan hubungan antara level konsentrasi ekstrak khamir terhadap konsentrasi asam glutamat dapat dilihat pada Tabel 1. Hasil analisis tersebut menunjukkan bahwa perbedaan konsentrasi ekstrak khamir yang digunakan memiliki korelasi yang sangat kuat terhadap konsentrasi asam glutamat pada sampel moromi M0 $(\mathrm{R}=0,921)$ dan korelasi yang kuat terhadap konsentrasi asam glutamat pada sampel moromi M1, M2, dan M3 ( $R=0,862,0,850$, dan 0,887$)$. Hasil ini sebanding dengan korelasi intensitas warna cokelat. Penambahan ekstrak khamir mempercepat fermentasi moromi sehingga dihasilkan asam amino bebas yang lebih tinggi sebagaimana ditunjukkan pada hasil analisis asam glutamat bebas.

\section{Karakteristik Moromi pada Hari Fermentasi ke-63}

Pada akhir fermentasi yaitu hari ke-63, penggunaan ekstrak khamir dengan konsentrasi $0,50 \% \mathrm{~b} / \mathrm{v}$ dapat menghasilkan moromi dengan karakteristik yang signifikan lebih baik dibanding moromi lain (M0, M1, dan M2) $(p<0,05)$. Hal tersebut dapat terlihat dari hasil analisis intensitas warna cokelat, total gula, total padatan terlarut, total asam tertitrasi, dan konsentrasi asam glutamat. Ekstrak khamir dapat menyediakan nutrisi tambahan bagi mikroorganisme selama fermentasi garam. Meskipun demikian, total gula, asam tertitrasi, dan konsentrasi asam glutamat pada sampel moromi lebih rendah dibanding dengan moromi hasil penelitian terdahulu (Singracha et al., 2017; Yanfang et al., 2009). Hal tersebut menunjukkan bahwa penggunaan bahan baku tunggal yaitu kacang kedelai memberi pengaruh yang besar terhadap komposisi akhir dari moromi ke- cap kedelai. Selain itu, rendahnya kandungan asam organik yang dihasilkan selama fermentasi mengakibatkan khamir tidak dapat tumbuh pada moromi sehingga senyawa aroma yang terbentuk terbatas.

\section{SIMPULAN}

Selama fermentasi garam, terjadi peningkatan pada total asam tertitrasi dan konsentrasi asam glutamat. Intensitas warna cokelat, total padatan terlarut, dan total gula mengalami kenaikan hingga hari fermentasi ke-35 dan menurun pada periode selanjutnya. Penambahan ekstrak khamir menghasilkan moromi dengan karakteristik kimia yang lebih baik dibanding moromi tanpa ekstrak khamir. Penggunaan konsentrasi ekstrak khamir sebesar $0,5 \% \mathrm{~b} / \mathrm{v}$ dapat menyediakan nutrisi dengan jumlah yang lebih tinggi sehingga menghasilkan moromi dengan total gula, total asam tertitrasi, dan konsentrasi asam glutamat yang signifikan lebih tinggi dibanding sampel moromi lain (M0, M1, dan M2). Meskipun demikian, moromi yang dihasilkan memiliki total gula, total asam tertitrasi, dan konsentrasi asam glutamat yang rendah akibat penggunaan kacang kedelai sebagai bahan baku tunggal.

\section{DAFTAR PUSTAKA}

AOAC, 2012. Official methods of analysis of AOAC International, 19th ed. AOAC International, Gaithersburg

Benthin, -S., Villadsen, -J., 1996. Amino acid utilization by Lactococcus lactis subsp. cremoris FD1 during growth on yeast extract or casein peptone. Journal of Applied Bacteriology. 80, 65-72. https:// doi.org/10.1111/j.1365-2672.1996. tb03191.x

Böehringer Mannheim, 2012. L-Glutamic acid: Colorimetric-method. Böehringer Mannheim GmbH-Biochemicals, Mannheim, Germany

Campagnol, P, C, -B., dos Santos, B, -A., Wagner, -R., Terra, N, -N., Pollonio, M, A, -R., 2011. The effect of yeast extract addition on quality of fermented sausages at low $\mathrm{NaCl}$ content. Meat Science. 87, 290-298. https://doi. org/10.1016/j.meatsci.2010.11.005 
Chen, -Q., Ding, -J., Cai, -J., Sun, -Z., Zhao, -J., 2012. Simultaneous measurement of total acid content and soluble salt-free solids content in chinese vinegar using near-infrared spectroscopy. Journal of Food Science. 77, 222-227. https:// doi. org/10.1111/j.1750-3841.2011.02549.x

Feng, -Y., Suo, -Y., Zhao, -H., Cai, -Y., Cui, -C., Sun-Waterhouse, -D., Zhao, -M., 2015. Characterisation of aroma profiles of commercial soy sauce by odour activity value and omission test. Food Chemistry. 167, 220-228. https://doi. org/10.1016/j.foodchem.2014.06.057

Gao, -X., Cui, -C., Ren, -J., Zhao,-H., Zhao, -Q., Zhao, -M., 2011. Changes in the chemical composition of traditional Chinesetype soy sauce at different stages of manufacture and its relation to taste. International Journal of Food Science Technology. 46, 243-249. https://doi. org/10.1111/j.1365-2621.2010.02487.x

Gao, X, -L., Chui, -C., Zhao, H, -F., Zhao, m, -M., Yang, -L., Ren, J, Y., 2010. Changes in volatile aroma compounds of traditional chinese-type soy sauce during moromi fermentation and heat treatment. Food Science and Biotechnology. 19, 889-898. https://doi.org/10.1007/s10068-010-0126-7

Hakobyan, -L., Gabrielyan, -L., Trchounian, -A., 2012.. Yeast extract as an effective nitrogen source stimulating cell growth and enhancing hydrogen photoproduction by Rhodobacter sphaeroides strains from mineral springs. International Journal of Hydrogen Energy. 37, 6519-6526. https://doi.org/10.1016/j. ijhydene.2012.01.077

Han, B, -Z., Ma, -Y., Rombouts, F, -M., Nout, M, J, -R., 2003. Effects of temperature and relative humidity on growth and enzyme production by Actinomucor elegans and Rhizopus oligosporus during sufu pehtze preparation. Food Chemistry. 81, 27-34. https://doi. org/10.1016/S0308-8146(02)00347-3

Hoang, N, -X., Ferng, -S., Ting, C, -H., Huang, W, -H, Chiou, R, Y, -Y., Hsu, C, -K., 2016. Optimizing the initial moromi fermentation conditions to improve the quality of soy sauce. LWT. 74, 242-250. https://doi.org/10.1016/j. lwt.2016.07.049

Ito, -K., Koyama, -Y., Hanya, -Y., 2013. Identification of the glutaminase genes of Aspergillus sojae involved in glutamate production during soy sauce fermentation. Bioscience, Biotechnology, and Biochemistry. 77, 1832-1840. https://doi. org/10.1271/bbb.130151

Lertsiri, -S., Maungma, -R., Assavanig, -A., Bhumiratana, -A., 2001. Roles of the maillard reaction in browning during moromi process of thai soy sauce. Journal of Food Processing and Preservation. 25, 149-162. https://doi. org/10.1111/j.1745-4549.2001.tb00450.x

Li, -M., Liao, -X., Zhang, -D., Du, -G., Chen, -J., 2011. Yeast extract promotes cell growth and induces production of polyvinyl alcohol-degrading enzymes. Enzyme Research. https://doi. org/10.4061/2011/179819

Lioe, H, -N., Apriyanto, -A., Takara,-K., Wada, -K., Naoki, -H., Yasuda, -M., 2004. Low molecular weight compounds responsible for savory taste of Indonesian soy sauce. Journal of Agricultural and Food Chemistry. 52, 5950-5956. https://doi. org/10.1021/jf049230d

Narvhus, JA, Axelsson, L. 2003. 'Lactic Acid Bacteria'. Dalam B. Caballero. Encyclopedia of Food Sciences and Nutrition. Academic Press. https://doi. org/10.1016/b0-12-227055-x/00673-8

Palupi, N,-S., Sitorus, S, -R., Kusnandar, -F., 2015. Perubahan alergenisitas protein kacang kedelai dan kacang bogor akibat pengolahan dengan panas. Jurnal Teknologi dan Industri Pangan. 26, 222-231. https:/ / doi. org/10.6066/jtip.2015.26.2.222

Pejin, -J., Radosavljević, -M., Tanackov, -S, -K., Vuković, A, -D., Mojović, -L., 2017. Lactic acid fermentation of brewer's spent grain hydrolysate by Lactobacillus rhamnosus with yeast extract addition and $\mathrm{pH}$ control. Journal of The Institute of Brewing. 123, 98-104. https:// doi.org/10.1002/jib.403

Pomeranz, Y, Meloan, CE. 1994. 'Carbohydrates'. Dalam Pomeranz Y, Meloan CE. (Ed.), Food Analysis: Theory and Practice. Chapman \& Hall, Inc., New York, USA

Röling, W, F, -M., Timotius, K, -H., Prasetyo, A, -B., Stouthamer, A, -H., Van Verseveld, H, -W. 1994. Changes in microflora and biochemical composition during the Baceman stage of traditional indonesian kecap (soy sauce) production. Journal of Fermentation and Bioengineering. 77, 62-70. https://doi. org/10.1016/0922-338X(94)90210-0 
Singracha, -P., Niamsiri, -N., Visessanguan, -W., Lertsiri, -S., Assavanig, -A., 2017. Application of lactic acid bacteria and yeasts as starter cultures for reducedsalt soy sauce (moromi) fermentation. LWT. 78, 181-188. https://doi. org/10.1016/j.lwt.2016.12.019

Smith, E, -A., Myburgh, -J., Osthoff, -G., de Wit, -M., 2014. Acceleration of yoghurt fermentation time by yeast extract and partial characterisation of the active components. Journal of dairy Research. 81(4), 417 - 423. https://doi. org/10.1017/S0022029914000429

Song, Y, -R., Jeong, D, -Y., Baik, S, -H., 2015.. Monitoring of yeast communities and volatile flavor changes during traditional korean soy sauce fermentation. Journal of Food Science. 80, 2005-2014. https://doi. org/10.1111/1750-3841.12995

Udomsil, -N., Rodtong, -S., Tanasupawat, -S., Yongsawatdigul, -J., 2010. Proteinase-producing halophilic lactic acid bacteria isolated from fish sauce fermentation and their ability to produce volatile compounds. International Journal of Food Microbiology. 141, 186-194. https:/ / doi.org/10.1016/j.ijfoodmicro.2010.05.016
Vieira, E, -F., Carvalho, -J., Pinto, -E., Cunha, -S., Almeida, A, -A., Fereira, I, M, P, L, V, -O., 2016. Nutritive value, antioxidant activity and phenolic compounds profile of brewer's spent yeast extract. Journal of Food Composition and Analysis. 52, 44-51. https://doi.org/10.1016/j. jfca.2016.07.006

Yanfang, -Z., Lijuan, -W., Wenyi, -T., 2009. Biochemical changes in low-salt fermentation of solidstate soy sauce. African Journal of Biotechnology. 8(24), 70287034. https://www.ajol.info/index. $\mathrm{php} / \mathrm{ajb} /$ article/view/68790

Zhang, -L., Zhou, -R., Cui, -R., Huang, -J., $\mathrm{Wu},-\mathrm{C} ., 2016$. Characterizing soy sauce moromi manufactured by highsalt dilute-state and low-salt solidstate fermentation using multiphase analyzing methods. Journal of Food Science. 81(11), C2639-C2646. https:/ / doi.org/10.1111/1750-3841.13516

Zhang, -L., Zhang, -L., Xu, -Y., 2020. Effects of Tetragenococcus halophilus and Candida versatilis on the production of aroma-active and umami-taste compounds during soy sauce fermentation. Journal of the Science of Food and Agriculture. 100, 2782-2790. https:// doi.org/10.1002/jsfa.10310 